\title{
Features of education of female students in modern educational institutions
}

\author{
Marina Elagina, Alisa Achina*, and Anastasia Lomaka \\ Don State Technical University, 344003, Rostov-on-Don, Russia
}

\begin{abstract}
Today, both in science and in everyday life, there is an increased interest in the concept of the human body. For a modern person, his body becomes that essential condition that largely determines professional, social and even personal success. It can even be said that the concept of the body is today one of the aspects of the social concept of a person and his place in society. Indeed, there is a clear trend towards an increase in the consumption of services aimed at meeting the need for the formation of a healthy and beautiful body: sports clubs and gyms, home exercise equipment, diet food, body shaping services in a variety of ways, etc. The conducted research has shown that despite the elaboration of the question of self-physical in theoretical terms, there is a certain lack of research in this area with a practical focus. Today, in state policy, the priority is to orient the population towards a healthy lifestyle. Consequently, for psychologists, the targeting of psychotherapy methods should be to help people with different attitudes to a healthy lifestyle. In order for such recommendations to be really useful and scientifically substantiated, it is advisable to identify significant differences in the understanding of the physical self by people with different attitudes towards a healthy lifestyle.
\end{abstract}

\section{Introduction}

The question of a person's perception of his physical image is of interest to representatives of various scientific fields. Psychology, sociology, medicine pay great attention to the preservation of the psychological and physical health of a person.

To study the phenomenon of the physical I, let us trace the dynamics of its study in psychology. Various psychological directions approach its study through the structure of the self-concept. The physical self is described as "body schema", "body image", "appearance". At the time of this writing, researchers have different points of view. However, the problem of the physical image of the $I$ was reflected in both foreign and domestic studies [1].

W. James described the structure of personality, in which one of the elements highlighted the "bodily I". He defined the constituent elements of the concept as a Physical Personality, a Social Personality and a Spiritual Personality. Here our interest is drawn to the description of the physical person [2]. The author attributed to it those components of

\footnotetext{
*Corresponding author: kochevanchik@mail.ru
} 
vital activity that a person identifies himself through a bodily organization. In this category, James included the body, clothing of a person, the result of labor, etc.

Many psychologists view body image as a component of self-awareness. This group of scientists includes R. Burns, M.Yu. Mdivani, E.T. Sokolova and others. They believe that the formation of the body image is included in all structures of self-awareness $[3,4]$. In the process of personality development, an idea is also formed about the requirements of others who interact with the personality.

In Russian psychology, a fairly extensive study of the question of the body image was carried out, which made it possible to single out some of its components: the external body, the boundaries of the body image and gender role. L.S. Vygotsky studied the influence of corporeality on the formation of a person's personality. Thanks to this, he came to the conclusion that problems with the perception of a person's bodily self, arise during deviations from its cultural and historical path [5].

In his works, Professor V.N. Kunitsyna is studying the external appearance of a person. Describing the perception of appearance, she pays attention to the unity of external data: physical appearance, design features and the transformation of her appearance associated with social requirements and fashion [6].

As mentioned earlier, one of the components of the body image is the boundary of the body image. Plesner divided the boundaries into two types: external and internal. The external border is manifested in the representation of the exterior, it can be presented in the form of images and representations. The inner boundary reflects the activity of the individual in the physical world $[7,8]$.

Sex-role affiliation unites self-awareness and personality behavior. Features of satisfaction with their appearance were studied by A. Mattes and J. Khan. They investigated the influence of stereotypes on attitudes towards their bodies in men and women [9]. As a result of the study, it was found that in women, physical attractiveness is an important component for high or low self-esteem. In contrast, in men, physical attractiveness did not significantly affect their self-esteem.

Self-esteem can be divided into two types: adequate and inadequate. Adequate selfesteem is understood as a real idea of a person about himself, his appearance, abilities. A person does not harbor any illusions, he can point out his strengths and weaknesses. Adequate self-esteem helps a person to accurately follow life goals [10]. Psychologists divide inadequate self-esteem into underestimated and overestimated. Inflated self-images are manifested in the fact that a person tries to be noticed. Such a person wants to dominate, takes responsibility for himself, reacts hard to criticism in his address. An individual with high self-esteem can reject the help of others, considers himself right in all matters. Obviously, by overestimating their abilities, these people have great risks of getting into situations that they cannot cope with [11].

People with low self-esteem are characterized by a desire to avoid general attention, sometimes it is confused with modesty. An individual with low self-esteem is highly dependent on the opinions of others, is very careful in actions and words, and is indecisive in making decisions. Such people need the approval of others, are very demanding of themselves and the world. Any failure can cause long-term experiences [12,13].

The formation of the self-concept of a person begins with ideas about himself as a whole, then in the field of view of the individual, individual traits and qualities of the personality appear. In his research, Burns often reiterates the idea that any attempt by a person to describe himself has a value judgment. This is due to the fact that the individual does not indifferently perceive reality. Since a person is inclined to give such evaluations, and in the self-concept it is necessary to consider self-esteem, which Burns calls "a personal judgment of one's own value" [14]. 
The next element of the self-concept, Burns highlights the emotional-value relationship, which he considers as self-esteem. The researcher pays attention to the significance of what is happening for the individual, to his reactions, i.e. on personal judgments. This phenomenon can provoke an individual to feel his own importance, self-respect. This leads to self-acceptance or the opposite feeling if the individual underestimates their results. It is these characteristics that Burns considers necessary to consider in the self-concept [15].

Summing up, we can state the sufficient elaboration of the question of the I-physical in theoretical terms. Despite this, there is a certain lack of practical research in this area. Today, in state policy, the priority is to orient the population towards a healthy lifestyle. Consequently, for psychologists, the targeting of psychotherapy methods should be to help people with different attitudes to a healthy lifestyle. In order for such recommendations to be really useful and scientifically substantiated, it is advisable to identify significant differences in the understanding of the physical self by people with different attitudes towards a healthy lifestyle.

\section{Materials and methods of research}

Based on theoretical assumptions, we formulated the purpose of the study - to study the features of self-attitude and its connection with the level of satisfaction with their physical I of female students. The hypothesis of the research was the assumption that the indicators of self-attitude of female students may be associated with the peculiarities of the perception of their image.

To identify the peculiarities of the perception of one's physical self-image in this work, we used the test method, the method of collecting, systematizing and analyzing data, methods of mathematical statistics. For the statistical processing of the collected data, the SPSS program was used, and for the convenience of reading and writing the thesis, all the data were transferred to the Microsoft Word program. To assess the self-image of the respondents, we chose the questionnaire of O.A. Skugarevsky and S.V. Sivukha "Selfimage questionnaire". In this questionnaire, respondents were asked to rate 16 statements regarding their attitude to their own appearance. Each statement was assessed on a fourpoint scale, where the respondent receives 0 points for the answer "never", 1 point "sometimes", 2 - "often", 3 points - "always". Self-attitude test questionnaire (V.V. Stolin, S.R. Panteleev). Today, "self-attitude" is understood as a special form of consciousness, this is the property of a person to realize that he is a subject of activity and, moreover, a subject with specific psychological and socio-moral characteristics. The structure of selfawareness includes such components as self-esteem and self-attitude. In the course of the study, we analyzed the interpersonal relationships of the respondents. This analysis was carried out using the methodology of T. Leary "Diagnostics of interpersonal relations". This analysis allowed us to determine the prevailing type of respondents 'attitude to others, to themselves and their self-esteem, and to form the girls' idea of themselves and their ideal I.

Empirical object of research: students, total: 80 people, among whom 40 girls are completely satisfied with their physical I, and 40 were not satisfied with their appearance. The reliability of the data obtained was ensured by determining the significance of the differences using the quartile procedure using the SPSS computer program.

\section{Results}

At the first stage of the study, thanks to the data obtained using the "Self-Image Questionnaire" method, we divided the female students into two equal groups. The first group included female students who are not satisfied with their bodily I, and to the second 
group we included female students who are generally satisfied with their appearance but agree to minor changes.

Next, we compared the indicators of self-attitude with the level of satisfaction with their bodily self of girls. It is interesting that in the group of respondents who are dissatisfied with their external appearance, the level of self-attitude is higher than among female students who are generally (partially) satisfied with their appearance.

We have identified the differences between these groups in real and ideal self-image. They are presented in tables 1 and 2 .

Table 1. Real Me of girls

\begin{tabular}{|c|c|c|c|c|c|c|c|c|}
\hline & $\begin{array}{c}\text { Autho- } \\
\text { ritarian }\end{array}$ & $\begin{array}{c}\text { Sel- } \\
\text { fish }\end{array}$ & $\begin{array}{c}\text { Aggres- } \\
\text { sive }\end{array}$ & $\begin{array}{c}\text { Suspi- } \\
\text { cious }\end{array}$ & $\begin{array}{c}\text { Subor- } \\
\text { dinate }\end{array}$ & $\begin{array}{c}\text { Depen- } \\
\text { dent }\end{array}$ & $\begin{array}{c}\text { Frien- } \\
\text { dly }\end{array}$ & $\begin{array}{c}\text { Altru- } \\
\text { istic }\end{array}$ \\
\hline $\begin{array}{c}\text { Comp- } \\
\text { letely } \\
\text { satis- } \\
\text { fied } \\
\text { with } \\
\text { their } \\
\text { appea- } \\
\text { rance }\end{array}$ & 5.17 & 4.33 & 5.67 & 5 & 4.17 & 4.83 & 4.5 & 2.5 \\
\hline $\begin{array}{c}\text { Satisfied } \\
\text { with } \\
\text { appea- } \\
\text { rance }\end{array}$ & 5.21 & 5.21 & 6.71 & 5.1 & 5.36 & 4.71 & 4.86 & 4.79 \\
\hline $\begin{array}{c}\text { Not } \\
\text { satisfied } \\
\text { with } \\
\text { appea- } \\
\text { rance }\end{array}$ & 5.6 & 5.85 & 5.3 & 5.1 & 5.75 & 5.75 & 5.85 & 5.1 \\
\hline
\end{tabular}

Table 2. Ideal self of girls

\begin{tabular}{|c|c|c|c|c|c|c|c|c|}
\hline & $\begin{array}{c}\text { Autho- } \\
\text { ritarian }\end{array}$ & $\begin{array}{c}\text { Sel- } \\
\text { fish }\end{array}$ & $\begin{array}{c}\text { Aggres- } \\
\text { sive }\end{array}$ & $\begin{array}{c}\text { Suspi- } \\
\text { cious }\end{array}$ & $\begin{array}{c}\text { Subor- } \\
\text { dinate }\end{array}$ & $\begin{array}{c}\text { Depen- } \\
\text { dent }\end{array}$ & $\begin{array}{c}\text { Frien- } \\
\text { dly }\end{array}$ & $\begin{array}{c}\text { Altru- } \\
\text { istic }\end{array}$ \\
\hline $\begin{array}{c}\text { Comp- } \\
\text { letely } \\
\text { satisfied } \\
\text { with their } \\
\text { appea- } \\
\text { rance }\end{array}$ & 7.17 & 5.17 & 3.33 & 4 & 3.67 & 4.83 & 4.5 & 2.5 \\
\hline $\begin{array}{c}\text { Satisfied } \\
\text { with } \\
\text { appea- } \\
\text { rance }\end{array}$ & 5.43 & 5.71 & 5.57 & 4.86 & 5.79 & 6 & 6.92 & 6.14 \\
\hline $\begin{array}{c}\text { Not } \\
\text { satisfied } \\
\text { with } \\
\text { appea- } \\
\text { rance }\end{array}$ & 5.3 & 6.3 & 5.3 & 4.1 & 4.75 & 5.6 & 6.9 & 5.65 \\
\hline
\end{tabular}

By displaying these girls in the picture, we can notice some differences in the ideal idea of their personality among girls. Girls with full acceptance of their appearance see their 
ideal image as a person confident in their abilities, they do not strive for leadership, but they are distinguished by perseverance in their actions. This indicator differs from the results of the other two groups, where girls pay less attention to this indicator in the ideal representation of themselves.

Thus, the psychological profiles of social orientations in girls with different levels of satisfaction with their bodies have certain differences, as evidenced by the diagnostic results.

Using the technique of V.V. Stolin, we were able to identify a different degree of a person's attitude to himself, to his own self.According to this indicator, the entire sample can be divided into three subgroups:

- girls with a high level of self-attitude;

- girls who have an average level of self-attitude;

- girls with a low level of self-attitude.

In the course of the study, it was found that the higher the girls' satisfaction with their bodies, the higher the level of self-attitude.

Also, this technique allowed us to reveal the level of expression of self-attitude indicators of female students. The greatest differences were revealed by significant differences on the scale of "autosympathy". The highest rates were demonstrated by a group of girls with a high level of self-attitude. Girls with a low level of self-attitude showed the lowest level of self-liking.

Analyzing the data obtained, we can say that girls with a low level of autosympathy and, in general, with a low level of self-attitude, have a tendency to self-blame. It is the only show in this group that is higher than in other groups. In this group, girls are observed to ascribe to themselves the blame for all negative events, which are not necessarily related to their personality.

Self-esteem is also low for these girls. During the translation of raw points, it was revealed that this group of subjects negatively perceives themselves as a person who is incorrect in their competence, girls may experience difficulties in behavior due to doubts about their actions.

In this group, girls show self-doubt, which can affect their perception of their professional and educational achievements. In the process of training, they usually make excessive demands on themselves. Self-acceptance scores are also low. Perhaps this indicator is also lowered due to a feeling of dissatisfaction with your body.

Girls with a high level of self-attitude are characterized by a high level of autosympathy, they are generally satisfied with themselves and their behavior. The attitude of other people towards their person is not so important to them as their opinion. Girls in this group of subjects are actively studying their personality, indicators of self-interest are at a fairly high position. The listed behavioral features strengthen girls' confidence in their abilities. The Overconfidence scale data support this conclusion. The girls in this group accept themselves as they are.

The results of the statistical assessment of the significance of differences between the groups according to the Kruskal-Wallis test are presented in Table 3.

Table 3. Results of comparing self-confidence using the Kruskal-Wallis test

\begin{tabular}{|c|c|c|c|}
\hline $\begin{array}{c}\text { Depend.: } \\
\text { Agressive (I) }\end{array}$ & Code & Sum of & Mean \\
\hline $\begin{array}{c}\text { Completely satisfied with } \\
\text { their appearance }\end{array}$ & 1 & 64,0000 & 10,66667 \\
\hline Satisfied with appearance & 2 & 341,5000 & 24,39286 \\
\hline $\begin{array}{c}\text { Not satisfied with } \\
\text { appearance }\end{array}$ & 3 & 414,5000 & 20,72500 \\
\hline
\end{tabular}


Table 4. Results of comparing self-confidence using the Kruskal-Wallis test

\begin{tabular}{|c|c|c|c|}
\hline $\begin{array}{c}\text { Depend.: } \\
\text { Confidence }\end{array}$ & Code & Sum of & Mean \\
\hline $\begin{array}{c}\text { Autosympathy is } \\
\text { pronounced }\end{array}$ & 1 & 430,0000 & 28,66667 \\
\hline $\begin{array}{c}\text { Autosympathy is } \\
\text { expressed }\end{array}$ & 2 & 223,0000 & 20,27273 \\
\hline $\begin{array}{c}\text { Autosympathy weak } \\
\text { expression }\end{array}$ & 3 & 167,0000 & 11,92857 \\
\hline
\end{tabular}

We compared the data in a similar way. A relationship was found between indicators of autosympathy and self-confidence. We can say that the higher the level of autosympathy among girls, the more confident they feel. They know how to objectively assess their success, there is no tendency to depreciate the results achieved. Self-confidence also affects the perception of a person by others. Confidence in one's abilities is reflected in a person's behavior and his attitude to the tasks set. In this case, the higher this confidence, the more willingly the person will work with new tasks. This is noticeable to others, which is why they begin to be more loyal to human mistakes, which in the future contributes to better results.

\section{Discussion}

Female students differ in the level of attitude to their body image at the level of absolute values, however, statistically significant differences in this sample of subjects between the levels of satisfaction with their bodies were not revealed, which may indicate the presence of a tendency towards pronounced differences.

The assumption that the indicators of girls satisfied with their appearance will be higher on the "self-esteem" scale was fully confirmed.

Self-attitude indicators of female students are associated with the peculiarities of their image perception: an increase in the self-accusation indicator is associated with a more pronounced dependent self-perception in the girls 'real self-image, high self-acceptance indicators are accompanied by the girls' desire to be more authoritarian, the desire to behave more aggressively is accompanied by an increase in personality self-understanding.

A group of girls with a high level of satisfaction with their physical image I feel the need for social approval and acceptance, a group of girls for whom autosympathy is of moderate importance, in an ideal self-image, strive for higher indicators than other girls. It is in this group of respondents that the greatest differences were revealed between real and ideal indicators on this scale. They are focused on social approval and acceptance, striving to help everyone, sometimes even to the detriment of their own needs. The lowest indicator of real friendliness is noted in the group of girls with the highest indicator of autosympathy, and girls with the lowest score for this indicator have the highest assessment of the perception of their real friendliness.

\section{Conclusions}

The concepts "body image" and "body concept" developed abroad continue to be the most popular in modern psychological science. The minimum amount of conceptual and conceptual contradictions is associated with the context of use and functional load of the category "body concept". The concept of the body is the formal knowledge of the individual about the structure, features of the external appearance and functional 
capabilities of his own body. Its content, being potentially verbalized, allows the subject to objectively designate and make his bodily experiences an object of communication. The boundaries of the "body image" category can be set as follows: the body image is interpreted by most authors as an independent personal formation; the bodily image is to a greater extent the result of perception and includes unconscious components; in the category of the body image, the subject's affective experiences of his body and attitudes towards it are recorded.

Parameters of body image and eating behavior during adolescence are in complex interrelationships: concern about body shape is highest among girls with restrictive eating behavior, at the same time, girls who note that they regularly overeat have the lowest rates of anxiety; the most critical assessments of their bodies are girls, whose eating behavior is characterized by diets and breakdowns. Feedback received from a love partner also plays an important role in shaping body image during adolescence: concerns about weight and body shape are significantly higher in those girls who receive negative feedback from their partner, slightly lower among those who do not receive any feedback. communication, and significantly lower for those who receive neutral or positive feedback.

Summing up, we can state the sufficient elaboration of the question of the I-physical in theoretical terms. Despite this, there is a certain lack of practical research in this area. Today, in state policy, the priority is to orient the population towards a healthy lifestyle. Consequently, for psychologists, the targeting of psychotherapy methods should be to help people with different attitudes to a healthy lifestyle. In order for such recommendations to be really useful and scientifically substantiated, it is advisable to identify significant differences in the understanding of the physical self by people with different attitudes towards a healthy lifestyle.

As a result of the study, the following conclusions were made:

- female students differ in the level of attitude to their body image at the level of absolute values, however, statistically significant differences in this sample of subjects between the levels of satisfaction with their bodies were not revealed, which may indicate a tendency towards pronounced differences;

- the assumption that the indicators of girls satisfied with their appearance will be higher on the "self-esteem" scale was fully confirmed;

- indicators of self-attitude of female students are associated with the peculiarities of the perception of their image: an increase in the indicator of self-accusation is associated with a more pronounced dependent self-perception in the real self-image of girls, high indicators of self-acceptance are accompanied by the desire of girls to be more authoritarian, the desire to behave more aggressively is accompanied by an increase in self-understanding of the individual;

- a group of girls with a high level of satisfaction with their physical image. I feel the need for social approval and acceptance, a group of girls in whom autosympathy is of moderate importance, in an ideal self-image, strive for higher indicators than other girls. It is in this group of respondents that the greatest differences were revealed between real and ideal indicators on this scale. They are focused on social approval and acceptance, striving to help everyone, sometimes even to the detriment of their own needs. The lowest indicator of real friendliness is noted in the group of girls with the highest indicator of autosympathy, and girls with the lowest score for this indicator have the highest assessment of the perception of their real friendliness.

\section{References}

1. M.M. Francis, V. Nikulina, C.S. Widom, Child Maltreatment 20 (3), 163-167 (2015). DOI: $10.1177 / 1077559514568892$. 
2. T.A. Lonshakova, E.V. Shevkova, Man in the world. The world in man: actual problems of philosophy, sociology, political science and psychology (Perm, 2013).

3. D.W. Winnicott, Child, family, and the outside world (Institute of General Humanitarian Research, Moscow, 2015).

4. S.G. Kaplan, E.M. Arnold, M.B. Irby, Infant, Child and Adolescent Nutrition 6 (1), 181-185 (2014). DOI: 10.1177/1941406413516001.

5. A.E. Bobrov, N.V. Gegel, O.Yu. Gurova, T.I. Romantsova, L.V. Savelyeva, Almanac of Clinical Medicine 32, 15-19 (2014).

6. A. Gladyshev, Rational Pharmacotherapy in Cardiology 10 (2), 108-110 (2014). DOI: 10.20996/1819-6446-2014-10-2-190-194

7. J. Ross, The Humanistic Psychologist 25 (2), 162-181(1997).

8. S. Tikhonova, Quality of preschool education: integration of science and practice (Kirov, 2013).

9. Y. Latzer, Y. Lavee, S. Gal, Journal of Family Issues 30 (9), 1201-1220 (2009).

10. J. Robboy, K.G. Anderson, Interpersonal Violence 20 (17), 3526-3529 (2011). DOI: $10.1177 / 0886260511403758$

11. V.A. Denisova, Humanitarian research in Eastern Siberia and the Far East 18 (2), 115 118 (2012).

12. U. Segercrantz, Group Analysis 4, 257-259 (2006).

13. I.P. Shulgina, Evaluation of the influence of the mother's image on the manifestations of alexithymia and empathy, as well as the peculiarities of the process of empathy in drug addicts $\mathrm{PhD}$ Thesis (SFedU, Rostov-on-Don, 2015).

14. C. Sikorski, C. Riedel, M. Uppa, B. Schulze, P. Werner, H. Konig, Scandinavian Journal of Public Health 40 (12), 271-277 (2012). DOI: 10.1177/1403494812443604.

15. A.L. Ostberg, I. Wikistrand, B.K. Bengtsson, Scandinavian Journal of Public Health 39, 98-105 (2011). DOI: 10.1177/1403494810391524. 